\title{
Correction to: Peripheral Neuropathy: No Longer the Land of Therapeutic Nihilism
}

\author{
Michael Polydefkis ${ }^{1} \cdot$ Charlotte J. Sumner ${ }^{1,2}$
}

Published online: 24 January 2022

(c) The American Society for Experimental NeuroTherapeutics, Inc. 2022

Correction to: Journal of Neurotherapeutics (2021) https://doi.org/10.1007/s13311-021-01177-5

The original article has been updated to correct the references and the issue date.

The original article has been corrected.

Publisher's Note Springer Nature remains neutral with regard to jurisdictional claims in published maps and institutional affiliations.

The original article can be found online at https://doi.org/10.1007/ s13311-021-01177-5.

\section{Michael Polydefkis} mpolyde@jhmi.edu

1 Department of Neurology, Johns Hopkins University School of Medicine, 855 North Wolfe Street, Rangos 234, Baltimore, MD 21205, USA

2 Department of Neuroscience, Johns Hopkins University School of Medicine, 855 North Wolfe Street, Rangos 234, Baltimore, MD 21205, USA 